\title{
Identifikasi Potensi Konflik \\ Pra dan Pasca Pendirian Rumah Ibadah DI Indonesla dan Upaya Untuk Mengatasinya \\ (Studi Kasus di Kota dan Kabupaten Bogor)*
}

\author{
(IDENTIFICATION OF POTENTIAL CONFLICTS OF PRE AND POST \\ CONSTRUCTION OF HOUSES OF WORSHIP IN INDONESIA AND \\ EFFORTS TO HANDLE; CASE STUDY IN THE CITY AND COUNTY OF \\ BOGOR)
}

\author{
Ahmad Mukri Aji \\ Majelis Ulama Indonesia (MUI) Kabupaten Bogor \\ Jl. Tegar Beriman Cibinong Kab. Bogor \\ E-mail: mukri.aji@gmail.com
}

\begin{abstract}
Religion contains teachings regarding the highest and absolute truth about human existence and the instructions for safe and happy life in this world and hereafter. Religion should not be a factor and moreover a source of conflict trigger, because religion itself appears as a system of beliefs that are in a culture that was born out of the community itself. Besides religion becomes a controller for the actions of the members of society in accordance with the values of culture and religion.
\end{abstract}

Keywords: Religion, Human Existence, Conflict

\begin{abstract}
Abstrak: Agama berisikan ajaran-ajaran mengenai kebenaran tertinggi dan mutlak tentang eksistensi manusia dan petunjuk untuk hidup selamat dan bahagia di dunia dan akhirat. Tidak semestinya agama menjadi faktor penyebab dan apalagi menjadi sumber pemicu konflik, karena agama itu sendiri tampil sebagai sebuah sistem keyakinan yang berada dalam kebudayaan yang lahir dari masyarakat itu sendiri, selain agama menjadi pengontrol bagi tindakan anggota masyarakat agar sesuai dengan nilai-nilai kebudayaan dan ajaran agamanya.
\end{abstract}

Kata Kunci: Agama, Eksistensi Manusia, Konflik

${ }^{*}$ Diterima tanggal naskah diterima: 12 Juli 2014, direvisi: 22 Juli 2014, disetujui untuk terbit: 20 September 2014. 


\section{Pendahuluan}

Negara Republik Indonesia adalah negara multikultural, yang memiliki keanekaragaman, baik dalam hal bahasa, suku, ras/etnis, dan agama. Keanekaragaman ini menjadikannya rawan untuk terjadi konflik, baik yang bersifat internal maupun bersifat eksternal. Tuduhan bahwa agama ikut andil dalam memicu konflik atau bahkan sebagai sumber konflik yang terjadi antar umat beragama memang sulit dibantah.

Di Indonesia ada enam agama yang diakui oleh pemerintah yaitu Islam, Kristen, Katolik, Hindu, Budha, dan Khonghucu. Pada hakikatnya, agama merupakan naungan sakral yang melindungi manusia dari situasi konflik kekacauan (chaos), dan kezaliman. Bagi para penganut (pengikutnya), agama berisikan ajaran-ajaran mengenai kebenaran tertinggi dan mutlak tentang eksistensi manusia dan petunjuk-petunjuk untuk hidup selamat dan bahagia di dunia dan akhirat (li sa`adatil basyari fi ma`asyihim wa ma`adihim). Sehingga, setiap insan umat beragama diharapkan dalam kehidupannya tampil sebagai manusia yang bertakwa kepada Tuhannya, bermoral, beradab dan berperilaku manusiawi yang tentunya berbeda dari cara-cara hidup hewan atau makhluk lainnya. ${ }^{1}$ Jadi tidak semestinya agama menjadi faktor penyebab dan apalagi sebagai pemicu konflik. Karena agama itu sendiri pada hakikatnya tampil sebagai sebuah sistem keyakinan dapat menjadi bagian inti dari sistem nilai yang ada dalam kebudayaan dari masyarakat, dan menjadi pendorong atau penggerak serta pengontrol bagi tindakan anggota masyarakat tertentu untuk tetap berjalan sesuai dengan nilai-nilai kebudayaan dan ajaran agamanya. ${ }^{2}$

Secara historis, pada masa kolonial, masyarakat Muslim di kepulauan Nusantara yang notabene terbanyak dan mayoritas penganutnya, merasa terancam dengan kebijakan politik kolonial yang memberi perlindungan terhadap kegiatan penyebaran agama Kristen. Akibatnya, hingga masa awal pasca kemerdekaan, kecurigaan Muslim terhadap Kristen dan Katolik dengan mudah terbentuk. Namun demikian, keputusan para pendiri Republik Indonesia, yang sebagian besar terdiri dari para ulama dan para pemuka dan tokoh agama Islam, untuk menetapkan Pancasila sebagai falsafah dasar negara dapat ditunjuk sebagai upaya sungguh-sungguh dalam mencari sistem

\footnotetext{
${ }^{1}$ Dadang Kahmad. Sosiologi Agama, (Bandung: ROSDA, 2000), hlm. 63.

2 Dadang Kahmad. Sosiologi Agama, hlm. 63.
} 
kenegaraan yang menjamin kerukunan dan pluralisme keagamaan, dan mengusung Konsep Negara Hukum. ${ }^{3}$

Konsep Negara hukum yang diusung Indonesia dituangkan di dalam Undang-Undang Dasar 1945 Pasal 1 ayat (3) yang mengandung arti bahwa diharapkan segala bentuk permasalahan dapat ditangani melalui proses dan mekanisme lahir dan hadirnya peraturan perundang-undangan yang baik. Akan tetapi, fenomena, fakta dan realitas sosial yang ada dalam masyarakat, terlihat beberapa dampak maupun kesenjangan yang lebih diakibatkan oleh munculnya beberapa peraturan perundang-undangan. Hal yang sama misalnya, dapat dilihat dalam Peraturan Bersama (PBM) Menteri Agama dan Menteri Dalam Negeri Nomor 8 Tahun 2006 dan Nomor 9 Tahun 2006 tentang Pedoman Pelaksanaan Tugas Kepala Daerah/Wakil Kepala Daerah dalam Pemeliharaan Kerukunan Umat Beragama, Pemberdayaan Forum Kerukunan Umat Beragama, dan Pendirian Rumah Ibadah. Hal tersebut sebagai implementasi dari kandungan Pasal 29 Undang-Undang Dasar 1945. Dapat dikalkulasikan bahwa hal-hal yang mengatur tentang pendirian rumah ibadah masih banyak terdapat kerancuan-kerancuan, sehingga pada akhirnya akan menimbulkan konflik terhadap umat beragama, terutama ketika landing di dataran lapangan lapis bawah di level kecamatan dan desa/kelurahan.

Makalah yang sangat sederhana ini mencoba menelaah lebih dekat Peran Pemerintah Daerah (Bupati/ Walikota) dalam mengaplikasikan PBM No. 8 Tahun 2006 dan Nomor 9 Tahun 2006 serta Mekanisme yang ditempuh untuk mengantisipasi Terjadinya Konflik Internal dan Eksternal Pra dan Pasca Pendirian Rumah Ibadah di Indonesia, dengan mengangkat sample kasus Pendirian Rumah Ibadah GKI Yasmin Wilayah Kota Bogor, dan Pendirian Rumah Ibadah Paroki Santo Yohanes Baptista Tulang Kuning Parung, serta Pendirian Rumah Ibadah Gereja Katolik Hati Kudus Citra Indah Jonggol, keduanya berada di wilayah Kabupaten Bogor.

\section{Upaya Pemerintah Dalam Melakukan Dialog dan Musayawarah Antar Umat Beragama}

Sebagaimana sudah dikemukakan pada bagian pendahuluan dan

\footnotetext{
${ }^{3} \mathrm{Abu}$ Rabi', "Christian-Muslim Relations in Indonesia: The Challenges of The Twenty-First Century" Jurnal Studia Islamika (Jakarta: IAIN Syarif Hidayatullah, 1998).
} 
mengutip pandangan Sudarto, ${ }^{4}$ pada masa kolonial, ketegangan dalam hubungan umat Islam dan umat Kristen lebih dipicu oleh kegiatan penginjilan (misionaris) yang mendapat bantuan besar dari pemerintahan penjajah Belanda, baik bantuan politik maupun finansial. Sementara pada masa Orde lama ketegangan antar dua komunitas umat beragama itu mencuat saat pembahasan UUD 1945 dan pada sidang Konstituante hasil Pemilu 1955. Dalam pembukaan UUD 1945 telah ditetapkan tujuh kata yang bernuansa islami, yang oleh kaum Kristen dianggap sebagai upaya pembentukan negara Islam, yang pada akhirnya, dengan kearifan dan kedewasaan para ulama dan para tokoh Islam demi terwujudnya Negara Kesatuan Republik Indonesia, dan sebagai hadiah terbesar Umat Islam dalam sejarah Perjuangan Republik Indonesia, dihapuskanlah tujuh kata: "Dengan kewajiban menjalankan Syariat Islam Bagi Pemeluknya."

Berangkat dari perkembangan situasi dan nuansa umat beragama yang tidak menguntungkan, maka pada tanggal 30 November 1967 diadakan "dialog dari atas" yang dipelopori oleh Pemerintah melalui Menteri Agama, KH. Muhammad Dahlan. Tetapi dialog yang melahirkan wadah "Musyawarah Antar Agama" itu belum dianggap berhasil menyelesaikan konflik antar agama. Sampai pada periode berikutnya dialog itu menemukan kembali momentum barunya pada masa Mukti Ali menjadi Menteri Agama yang mencoba merumuskan dialog dengan berpijak pada iktikad baik dan sikap saling percaya dari masing-masing komunitas agama. Karena itu, Mukti Ali menghidupkan kembali wadah Musyawarah Antar agama dengan melibatkan lebih banyak tokoh dan pemimpin agama, khususnya lahirnya Surat Keputusan Bersama (SKB) No. 01/BER/MDN-MAG/ Tahun 1969.

Sebenarnya sejak awal Orde Baru hingga sekarang, baik atas prakarsa pemerintah maupun masyarakat beragama itu sendiri dialog antar umat beragama telah dibangun, bahkan menjadi agenda nasional demi terciptanya stabilitas keamanan serta lancarnya pembangunan meskipun kemudian ada pihak yang menilai tidak berhasil, karena tidak adanya kesepakatan bersama berkenaan dengan prinsip-prinsip penyebaran agama. ${ }^{5}$ Bahkan rentangan masa antara tahun 1972-1977 tercatat pemerintah telah menyelenggarakan

\footnotetext{
4 Sudarta, Konflik Islam-Kristen, Menguak Akar Masalah Hubungan Antar umat Beragama di Indonesia, (Semarang: Pustaka Rizki Putra, 1999), hlm. 79-80.

5 Sumarthana, "Menuju Dialog Antar Iman”, Pengantar dalam Dialog : Kritik dan Identitas Agama, (Yogyakarta: Dian/ Interfedei, Seri Dian I/Tahun I, 1993), x-xi.
} 
dialog yang berlangsung di 21 kota dengan mengusung sosialisasi Toleransi Antar Umat Beragama. ${ }^{6}$

Pada dekade tahun 1980-an hingga saat ini prakarsa dialog dalam mewujudkan kerukunan antarumat beragama dan sosialisasi pemahaman pluralisme ini pun terus dilakukan, baik oleh para tokoh agama, intelektual muda maupun pemerintah sendiri, misalnya dialog yang diselenggarakan oleh International Conference on Religion and Peace (ICRP) yang diprakarsai oleh Johan Efendi dan kawan-kawan, dialog kelembagaan (Institutional Dialogue), yakni dialog antar delegasi berbagai organisasi agama yang melibatkan majelis-majelis agama yang diakui pemerintah, seperti Majelis Ulama Indonesia (MUI), Persatuan Gereja Indonesia (PGI), Konferensi Waligereja Indonesia (KWI), Parisada Hindu Darma dan Perwalian Umat Budha Indonesia (WALUBI) dan seterusnya.

Akan tetapi, realita yang ada dan kenyataannya sampai sekarang, ketegangan dan kerusuhan yang disebabkan oleh sentimen keagamaan di beberapa daerah, seperti di Situbondo, Tasikmalaya, Ketapang, Kupang, Ambon, Poso, Maluku dan seterusnya yang mengakibatkan hancurnya tempat-tempat ibadah seperti masjid, mushalla, dan gereja semakin bertambah parah kondisinya. Padahal upaya Pemerintah RI dalam menyelesaikan masalah konflik di Poso, yang melahirkan wadah bernama Perundingan Malino I dan ditindaklanjuti dengan Perundingan Malino II untuk penyelesaikan konflik Maluku terus digalang. Dengan perundingan Malino II ini diharapkan menghasilkan kemanfaatan yang berarti bagi terciptanya perdamaian dan kerukunan hidup antar umat beragama di Indonesia. Tetapi upaya inipun, sebagaimana yang kita saksikan bersama, belum juga mampu mengatasi dan mencegah timbulnya kembali konflik antar umat beragama. Fenomena di atas menunjukkan kesenjangan (gap) antara idealitas agama (das sollen) sebagai ajaran dan pesan-pesan suci Tuhan dengan realitas empirik yang terjadi dalam masyarakat (das sein).

\section{Gagasan Pembentukan Peraturan Bersama Menteri Agama dan Menteri Dalam Negeri (PBM)}

1. Proses Pembentukan PBM

${ }^{6}$ Jurnal Ulumul Qur'an, IV (1993), hlm. 4. 
Menteri Agama RI, Maftuh Basyuni telah menyatakan dalam sambutannya pada Acara Pembukaan Sosialisasi PBM, 19 April 2006 bahwa lahirnya SKB Nomor 1 Tahun 1969 memberikan motivasi kepada semua kelompok penganut agama di Indonesia untuk memiliki rumah ibadah berkembang dengan pesat. Misalnya sebagai perbandingan, jumlah rumah ibadah pada tahun 1977 dengan tahun 2004; Masjid (1977) berjumlah= 392.044., Masjid (2004) berjumlah= 643.834 (kenaikan sebesar 64\%). Gereja Kristen (1977) berjumlah=18.977, Gereja Kristen (2004) berjumlah= 43.909 (kenaikan sebesar 131\%). Gereja Katholik (1977) berjumlah= 4.934, Gereja Katholik (2004) berjumlah= 12.473 (kenaikan sebesar 153\%), sedangkan Rumah Ibadah Budha (1997) berjumlah=1.523, Rumah ibadah Budha (2004) bejumlah= 7.129 (kenaikan sebesar 368\%). Data tersebut telah diverifikasi dengan Dirjen Bimas Islam dan Penyelenggaraan Haji, Dirjen Bimas Kristen, Dirjen Bimas Katholik, serta Dirjen Bimas Hindu dan Budha. Meskipun demikian diakui pula bahwa di lapangan terkadang ada masalah yang mempengaruhi hubungan antar umat beragama, disebabkan oleh tidak jelasnya syarat-syarat yang diatur oleh SKB, dan kurangnya komunikasi antara pihak-pihak yang akan mendirikan rumah ibadah dengan umat beragama dan para pemeluk agama di sekitar rumah ibadah yang hendak dibangun.

Selanjutnya, pada tanggal 7 September 2005 telah dilakukan rapat bersama antara Menteri Dalam Negeri, Menteri Agama, Jaksa Agung, Kapolri, Menteri Hukum dan HAM, dan sejumlah pejabat lainnya dengan kesimpulan rapat bahwa SKB tersebut perlu disempurnakan dengan mengacu kepada Undang-Undang No. 32 Tahun 2004. Ada 10 kali pertemuan untuk merumuskan draft penyempurnaan SKB berlangsung dan selama setahun. Sedangkan pembahasan kesebelas (terakhir) dilakukan dengan Majelis Agama, yaitu: MUI (Majelis Ulama Indonesia), PGI (Persatuan Gereja di Indonesia), KWI (Konferensi Waligereja Indonesia), PHDI (Parisadha Hindu Dharma Indonesia), dan WALUBI (Perwakilan Umat Budha) dan dihadiri langsung oleh Menteri Agama dan Menteri Dalam Negeri. Hadirnya PBM ini menghilangkan keraguan sementara orang yang menyatakan bahwa pemerintah daerah tidak mempunyai kewenangan dan tanggungjawab di bidang keagamaan sesuai dengan Pasal 10 Undang-Undang No. 32 Tahun 2004 tentang Pemerintahan Daerah. Substansi PBM ini secara tersirat menegaskan bahwa yang dimaksud dengan kewenangan pemerintah pusat dalam bidang agama adalah pada aspek kebijakannya. Sedangkan pada aspek 
pelaksanaan pembangunan dan kehidupan keagamaan itu sendiri tentu saja dapat dilakukan oleh semua warga masyarakat Indonesia di seluruh tanah air termasuk oleh Pemerintahan Daerah.

\section{Isi dan Kandungan PBM}

PBM No. 9 Tahun 2006/No. 8 Tahun 2006 Tentang Pedoman Pelaksanaan Tugas Kepala Daerah/Wakil Kepala Daerah Dalam Pemeliharaan Kerukunan Umat Beragama, Pemberdayaan Forum Kerukunan Umat Beragama, dan Pendirian Rumah Ibadah ini berisi 10 Bab dan 31 Pasal. Pada prinsipnya PBM ini mengandung 3 Pedoman Pokok, yaitu: Pedoman Pokok Pertama: Pedoman tentang Tugas-tugas Kepala Daerah/Wakil Kepala Daerah dalam Pemeliharaan Kerukunan Umat Beragama sebagai bagian penting dalam Kerukunan Nasional. Ada 6 Pasal di Bab II, yaitu: Pasal 2 s.d. Pasal 7 yang mengatur tentang Pemeliharaan umat beragama di propinsi menjadi tugas dan kewajiban yang dibantu oleh Kepala Wilayah Kementerian Agama Propinsi.

Demikian juga, di level Kabupaten/Kota menjadi tugas dan kewajiban Bupati/Walikota. Pedoman Pokok Kedua: Pemberdayaan Forum Kerukunan Umat Beragama (FKUB). Ada 5 Pasal di Bab III yaitu: Pasal 8 s.d. Pasal 12, Pemberdayaan Forum Kerukunan Umat Beragama (FKUB). Keanggotaan FKUB terdiri atas pemuka-pemuka agama setempat. Jumlah anggota FKUB propinsi paling banyak 21 orang dan jumlah anggota FKUB Kabupaten/Kota paling banyak 17 orang. Pedoman Pokok Ketiga: Pendirian Rumah Ibadah. Ada 5 Pasal di Bab III yaitu: Pasal 13 s.d. Pasal 17 berkaitan dengan alasan pendirian rumah ibadah didasarkan kepada adanya keperluan nyata dan sungguh-sungguh berdasarkan komposisi jumlah penduduk bagi pelayanan umat beragama yang bersangkutan di wilayah kelurahan/desa (pasal 13 ayat (1)), serta dilakukan dengan tetap menjaga kerukunan umat beragama, tidak mengganggu ketentraman dan ketertiban umum, serta mematuhi peraturan perundang-undangan (Pasal 13 ayat 2).

Di samping itu, pendirian rumah ibadah harus memenuhi persyaratan administratif dan persyaratan teknis bangunan gedung (Pasal 14 ayat (1). Selain itu, pendirian rumah ibadah harus memenuhi beberapa persyaratan

${ }^{7}$ Lihat Sambutan Menteri Agama RI, Muhammad Maftuh Basyuni, pada Acara Sosialisasi PBM di Depdagri, 7 April 2006. 
khusus (pasal 14 ayat 2), yaitu: a. Daftar nama dan KTP pengguna rumah ibadah paling sedikit 90 orang yang disahkan oleh pejabat setempat sesuai dengan tingkat batas wilayah. b. Dukungan masyarakat setempat paling sedikit 60 orang yang disahkan oleh Lurah/Kepala Desa. c. Rekomendasi tertulis kepada Kantor Departemen Agama Kabupaten/Kota, dan d. Rekomendasi tertulis FKUB Kabupaten/Kota.

3. Pasal-Pasal Krusial PBM yang Dapat Memicu Konflik Internal dan Eksternal Umat Beragama.

Sebagaimana sudah dijelaskan bahwa hadirnya PBM adalah upaya pemerintah khususnya pemerintah daerah untuk dapat mengapresiasi dan melayani pendirian rumah ibadah dan menyadarkan para pihak pemuka dan tokoh agama serta para pengikut agama untuk selalu menyadari dan menaati terhadap peraturan perundang-undangan sebagai hukum positif yang berlaku, dan harus terjamin untuk menjaga semangat kerukunan umat beragama, serta menjaga ketentraman dan ketertiban masyarakat secara maksimal.

a. Aplikasi Pasal 14, ayat 1, 2, dan 3 Tentang Pendirian Rumah Ibadah

1) Pendirian rumah ibadah harus memenuhi persyaratan administartif dan persyaratan teknis bangunan gedung.

2) Selain memenuhi persyaratan sebagaimana dimaksud pada ayat (1) pendirian rumah ibadah harus memenuhi persyaratan khusus meliputi:

a) Daftar nama dan kartu tanda penduduk pengguna rumah ibadah paling sedikit 90 (sembilan puluh) orang yang disahkan oleh pejabat setempat sesuai dengan tingkat batas wilayah sebagaimana dimaksud dalam pasal 13 ayat (3).

b) Dukungan rakyat setempat paling paling sedikit 60 (enem puluh) orang yang disahkan oleh lurah/kepala desa.

c) Rekomendasi tertulis kepada kantor departemen agama kabupaten/kota; dan

d) Rekomendasi tertulis FKUB kabupaten/kota.

3) Dalam hal persyaratan sebagaimana dimaksud pada ayat (2) huruf a terpenuhi sedangkan persyratan huruf $b$ belum terpenuhi, pemerintah 
daerah berkewajiban memfasilitasi tersedianya lokasi pembangunan rumah ibadah.

Berdasarkan bunyi Pasal 14 ayat (1), (2), dan (3), maka juga terdapat beberapa kerancuan di antaranya:

Persyaratan yang mempergunakan kartu tanda penduduk, baik paling sedikit 90 orang untuk pengguna rumah ibadah maupun 60 orang sebagai dukungan masyarakat setempat sangat strategis untuk terlindunginya HAM baik bagi para pengguna rumah ibadah maupun masyarakat yang berada di lokasi didirikannya rumah ibadah dan terjadinya hubungan harmonis di antara pihak umat beragama. Akan tetapi, dalam dataran aplikatif di lapangan menjadi krusial dan menjadi pemicu konflik baik internal maupun eksternal intra dan antar umat beragama. Dalam mengumpulkan 90 KTP untuk para pengguna rumah ibadah, panitia pembangunan mengumpulkannya dengan mengambil KTP pengguna rumah ibadah yang bukan berasal dari KTP Desa atau Kelurahan sesuai dengan lokasi yang akan dibangun rumah ibadah tersebut. Yang memicu konflik, KTP pengguna rumah ibadah itu diambil dari Kecamatan dan bahkan dari Kabupaten/ Kota lain yang tidak ada kaitannya dengan lokasi rumah ibadah yang akan dibangun atau dibuatkan KTP fiktif bekerjasama dengan RT, RW dan Kades/Kalur dan bahkan menjebak tokoh agama yang diperalat untuk mendukungnya. Demikian juga, untuk 60 orang pendukung dari masyarakat sekitar lokasi sangat rawan dimanipulasi, dengan pendekatan uang atau pemberian sembako atau bakti sosial yang diberikan kepada 60 orang pendukung atau bahkan lebih jumlahnya. Dalam pembagian uang atau sembako menjelang Idul Fitri atau sapi untuk Idul Adha, atau dengan modus memberikan santunan untuk yatim di bulan Muharram yang semua itu dilakukan untuk mendapatkan simpati dan dukungan tertulis melalui tandatangan persetujuan, dan atau dukungan dalam bentuk fotocopy KTP yang semuanya itu didesain dan direkayasa. Dokumen tandatangan itu untuk kepentingan dukungan masyarakat dan bahkan tokoh masyarakat dimasukkan dalam Proposal Permohonan yang diajukan ke Bupati/Walikota melalui Kades/Kalur dan Camat Kepala Wilayah lokasi rumah ibadah itu akan dibangun.

Inilah bentuk rekayasa dalam bentuk manipulasi data sebagai kasus yang terjadi di GKI Yasmin Kota Bogor, Rumah Ibadah Paroki Santo Yohanes Baptista Tulang Kuning Parung, serta Pendirian Rumah Ibadah Gereja Katolik Hati Kudus Citra Indah Jonggol, di mana keduanya berada di wilayah Kab. Bogor. Dampak dari rekayasa ini (yang terbukti di Pengadilan untuk kasus GKI Yasmin, atau terbuka setelah dilakukan validasi dan verifikasi oleh pihak Kemenag dan FKUB), telah terjadi konflik internal di antara tokoh agama (dengan mengatasnamakan ulama) baik dari pihak yang mendukung dan yang 
menolak terjadinya unjuk rasa dan demo karena merasa dilecehkan di depan kantor Desa, atau kantor Kecamatan, atau Kantor Bupati, atau di depan kantor DPRD, apalagi terkesan ada pembiaran dari penegak hukum, dan atau dianggap ikut berpihak kepada salah satu pihak yang melakukan konflik, yang menjadikan rendah dan turun muruah dan wibawa para penegak hukum. ${ }^{8}$

b. Aplikasi Pasal 18, ayat 1,2, dan 3 Tentang Izin Sementara Pemanfaatan Bangunan Gedung.

1). 18 ayat (1), (2) dan (3):

1). Pemanfaatan bangunan gedung bukan rumah ibadah sebagai rumah ibadah sementara harus mendapat Surat Keterangan Pemberian Izin Sementara (SKPIS) dari Bupati/Walikota dengan memenuhi persyaratan;

a. Laik fungsi; dan

b. Pemeliharaan kerukunan umat beragama serta ketentraman dan ketertiban masyarakat.

2). Persyaratan laik fungsi sebagaimana dimaksud pada ayat (1) huruf a mengacu kepada peraturan perundang-undangan tentang bangunan.

3). Persyaratan pemeliharaan Kerukunan Umat Beragama serta ketentraman dan ketertiban masyarakat sebagaimana dimaksud pada ayat (1) huruf b meliputi:

a. Izin tertulis pemilik bangunan;

b. Rekomendasi tertulis Lurah/Kepala Desa

c. Pelaporan tertulis kepada FKUB Kabupaten/Kota; dan

d. Pelaporan tertulis kepada Kepala Kantor Departemen Agama Kabupaten/Kota.

Berdasarkan bunyi Pasal 18 ayat 1 s.d. 3 tentang izin sementara pemanfaatan bangunan gedung, dalam dataran aplikasinya terdapat kerancuan yang mengakibatkan terjadinya konflik:

Pasal 18 ini dipahami bahwa rumah tinggal, ruko, atau gedung serbaguna, atau bangunan tenda itu dapat dijadikan tempat sementara untuk melaksanakan ibadah, dengan catatan disertai dengan surat izin sementara

${ }^{8}$ Wikipedia bahasa Indonesia, GKI Yasmin. 
dari Bupati/Walikota untuk melaksanakan ibadah. Akan tetapi, di lapangan ternyata berbeda halnya, pelaksanaan ibadah dilakukan di rumah tinggal, ruko, gedung serbaguna atau bangunan tenda dengan jamaat yang bukan berasal dari luar lokasi, atau bahkan tidak ada seorangpun jamaah dari lokasi tersebut, dengan dukungan dari beberapa warga, atau RT yang penuh dengan rekayasa. ${ }^{9}$

Lama kelamaan rumah tinggal, gedung serba guna, dan ruko itu diklaim dengan papan nama sebagai rumah ibadah yang seolah-olah sudah resmi. Inilah yang manjadi pemicu konflik yang sangat sensitif dari para warga sekitar lokasi dan para tokoh masyarakat yang merasa tidak mengetahui adanya izin itu, yang mengakibatkan terjadi konflik sosial horizontal antara warga masyarakat di lokasi itu antara yang mendukung dan yang tidak mendukung, serta terjadinya kecurigaan dengan tokoh masyarakat, baik dengan lingkungan RT, RW atau dengan Kadesnya. Atau lebih dari itu, sebagian masyarakat yang menolak atas hadirnya rumah ibadah itu melakukan demo baik ke Camat Kepala Wilayah Kecamatan, atau ke kantor Bupati/Walikota, dan ke kantor DPRD setempat.

Berdasarkan uraian di atas, dapat dipahami bahwa terjadinya konflik internal dan bahkan konflik horizontal dan konflik sosial itu disebabkan oleh belum tersosialisasikan muatan dan isi PBM ini, belum ditatinya secara seksama norma, aturan serta hukum yang ada dalam PBM, dan belum maksimalnya peran dan fungsi Kepala Daerah, FKUB, dan Kementerian Agama untuk mengawal PBM ini.

\section{Antisipasi Konflik Akibat Pendirian Rumah Ibadah}

Sebagaimana telah dikemukakan bahwa PBM No. 9 Tahun 2006 dan No. 8 Tahun 2006 Tentang Pedoman Pelaksanaan Tugas Kepala Daerah/Wakil Kepala Daerah Dalam Pemeliharaan Kerukunan Umat Beragama, Pemberdayaan Forum Kerukunan Umat Beragama, dan Pendirian Rumah

${ }_{9}$ Hasil pendekatan melalui uang atau bentuk bhakti sosial dalam bentuk Sembako menjadi dukungan tandatangan dari warga sekitar atau Ketua RT untuk mendukung pelaksanaan Ibadah di rumah tinggal, ruko, dan gedung serba guna. Padahal tandatangan itu di sehelai kertas sebagai daftar hadir yang dimanipulasi menjadi lampiran dukungan dan tidak keberatan seperti kasus Paroki Tulang Kuning Parung, Gereja di Limus Nunggal Cileungsi. Pemberian uang tersebut dilakukan untuk pendekatan kepada Kadesnya, atau ke camatnya atau ke tokoh agamanya. 
Ibadah ini berisi $10 \mathrm{Bab}, 31$ Pasal. Semua ayat dan pasal tersebut telah mengatur: Mekanisme dan Prosedural Pendirian Rumah Ibadah secara elegan, dari mulai menggagas dan melakukan kegiatan Pra Pendirian Rumah Ibadah sampai dengan keluarnya IMB dari Bupati/Walikota, dan Pasca Pendirian Rumat Ibadah digunakan oleh para jamaah dalam keadaan damai, tenteram dan tidak meresahkan masyarakat sekitar lokasi rumah ibadah yang telah diresmikan. Di samping itu, PBM ini menyadarkan semua pihak dan para pihak pemeluk agama yang akan membangun rumah ibadah atau mengadakan kegiatan ibadah di tempat sementara, semua tahapan kegiatan itu mesti mengacu kepada hukum positif yang berlaku sebagai pijakan dan pedoman yaitu Peraturan Bersama (PBM) Menteri Agama dan Menteri Dalam Negeri Nomor 9 Tahun 2006 dan Undang-Undang No. 8 Tahun 2006. Di samping itu, peran maksimal dari Pimpinan Daerah Bupati/Walikota termasuk struktur yang ada di bawahnya mulai dari RT, RW, Kalur/Kades dan Camat, dan peran maksimal dari Kantor Urusan Agama (KUA) juga Kementerian Agama mempunyai peranan strategis untuk memberikan kesadaran hukum kepada setiap warga masyarakat pemeluk agama yang berdomisili di wilayahnya.

\section{Fenomena dan Fakta Pendirian Rumah Ibadah Di Kota dan Kabupaten Bogor}

Secara sosiologis, sensisitifitas masyarakat terhadap Pendirian Rumah Ibadah apalagi yang tidak sefaham atau tidak seagama itu begitu sangat tinggi. Untuk pendirian rumah ibadah yang seagama saja tidak mudah untuk diterima. Misalnya, FKUB Kabupaten Bogor memberikan rekomendasi untuk tidak dibangun Masjid yang ditolak oleh warga di sekitar lokasi karena jamaah yang akan membangun masjid itu menganut faham Ahmadiyah (Kecamatan Cibungbulang Kabupaten Bogor, 2007), atau yang menganut faham LDII (Kecamatan Gunung Puteri, Kabupaten Bogor), atau menganut Islam Hanif yang ustadznya adalah Pendeta dengan kitab sucinya "al-kitab" (Kecamatan Bojong Gede Bogor). Apalagi pendirian rumah ibadah di lokasi yang berbeda agama yang dianut, ketika dibangun dengan tidak ada dukungan dari warga setempat dan belum ada IMB dari Bupati, dan atau diketemukan ada manipulasi data, tidak sesuai dengan mekanisme dan prosedural PBM, hal tersebut akan terjadi konflik sosial dan bahkan horizontal. Akan tetapi, yang menggembirakan terhadap rumah ibadah 
(Gereja, Vihara, Kelenteng) yang sudah ada IMB-nya tidak ada sama sekali gangguan dari masyarakat sekitarnya dan nampak toleransi umat beragama begitu tinggi. Sehingga MUI Kabupaten Bogor meminta kepada Pemerintah Daerah Kabupaten Bogor untuk memfasilitasi IMB Masjid, Ponpes, Mushalla dan Majelis Ta`lim, sekaligus sertifikasi tanah wakafnya.

\section{Permasalahan Krusial Kasus GKI Yasmin Kota Bogor}

Gereja Kristen Indonesia - Yasmin atau disingkat GKI-Yasmin adalah Gereja Kristen Protestan yang berdiri di Kota Bogor di bawah naungan Gereja Kristen Indonesia yang berpusat di Jakarta. Gereja ini didirikan di Jalan Abdullah Nuh Jawa Barat. GKI ini memperoleh nama Yasmin karena berlokasi di Perumahan Taman Yasmin.

Polemik keberadaan GKI Yasmin bermula adanya penolakan oleh 30 orang warga Kelurahan Curug Mekar pada tanggal 10 Januari 2006. Pada tanggal 22 Januari 2008, Muspika (Musyawarah Pimpinan Daerah) beserta 80 tokoh masyarakat Kelurahan Curug Mekar mengadakan rapat dan hasilnya pada tanggal 25 Januari 2006 mereka melayangkan surat kepada Walikota Bogor untuk mencabut IMB GKI Yasmin. Alasan yang mereka sampaikan adalah adanya dugaan pemalsuan tandatangan warga pendukung untuk memperoleh IMB pembangunan GKI Yasmin. Menanggapi permintaan warga, IMB GKI Yasmin dibekukan melalui Surat Kepada Dinas Tata Kota dan Pertamanan Kota Bogor No. 503/208-DTKP tahun 2008.

Ada beberapa alasan warga menentang pembangunan GKI Yasmin adalah:

a. Pembagian dana pembangunan wilayah dan membagikan transport. Dalam pembagian dana tersebut, warga diminta menandatangani tanda terima bantuan keuangan, selanjutnya tanda tangan dipotong dan ditempelkan pada kertas yang kop suratnya berisi pernyataan warga tidak keberatan atas pembangunan gereja.

b. Pembangunan GKI Yasmin tidak memiliki rekomendasi tertulis dari Kepala Departemen Agama setempat.

c. GKI Yasmin tidak memiliki dan tidak memenuhi minimal pengguna sejumlah 40 Kepala Keluarga yang berdomisili di wilayah setempat.

d. GKI Yasmin tidak mendapatkan izin dari warga setempat. 
e. GKI Yasmin tidak mendapatkan rekomendasi Kepala Kementerian Agama dan Forum Kerukunan Umat Beragama (FKUB) Kab. Bogor. ${ }^{10}$

\section{Permasalahan Krusial Pembangunan Gereja Paroki Santos Yohanes Baptista Tulang Kuning Kecamatan Parung Kabupaten Bogor}

Gereja Paroki Tulang Kuning Parung berlokasi di sebuah rumah tinggal pendetanya dengan dibangun tenda permanen di tengah pemukiman muslim daerah Kampung Tulang Kuning Desa Waru Kecamatan Parung Kabupaten Bogor. Para warga menolak kehadiran Gereja Paroki yang sama sekali tidak ada izin, hanya dengan modal nekad mereka melakukan kegiatan ibadah di rumah tempat tinggal yang dibangun tenda permanen itu.

Ada beberapa alasan warga menentang pembangunan Gereja Paroki Tulang kuning adalah:

a. Pembagian dana pembangunan wilayah dan membagikan transport dan bingkisan Idul Fitri. Dalam pembagian dana tersebut, warga diminta menandatangani tanda terima bantuan keuangan, selanjutnya tanda tangan dipotong dan ditempelkan pada kertas yang kop suratnya berisi pernyataan warga tidak keberatan atas pembangunan gereja.

b. Pelaksanaan ibadah di rumah tinggal dan tenda permanen Gereja Paroki tidak memiliki rekomendasi tertulis dari Kepala Kantor Kementerian Agama setempat.

c. Gereja Paroki Tulang Kuning tidak memiliki dan tidak memenuhi minimal pengguna sejumlah 40 Kepala Keluarga yang berdomisili di wilayah setempat. Sekalipun jamaahnya ratusan dihadirkan dari Depok, Tangsel, dan Jakarta selatan.

d. Gereja Paroki Tulangkuning tidak mendapatkan izin dari warga setempat.

e. Tidak mendapatkan rekomendasi dari Kepala Kementerian Agama Kabupaten Bogor dan Forum Kerukunan Umat Beragama (FKUB) Kab. Bogor tentang rumah tinggal dan tenda permanen yang djadikan tempat ibadah sementara, dan 3 surat teguran Bupati Kab. Bogor untuk menghentikan berbagai kegiatan ibadah dan diminta untuk mengurus

${ }^{10}$ Info Data diambil dari FKUB Kota Bogor. 
IMB-nya sesuai dengan mekanisme dan proseduralnya, semuanya sama sekali tidak diindahkan. ${ }^{11}$

\section{Permasalahan Krusial Pembangunan Gereja Katholik Hati Kudus Yesus Citra Indah Jonggol Kecamatan Jonggol Kabupaten Bogor}

Gereja Katholik Hati Kudus Yesus Citra Indah Jonggol Kec. Jonggol Kab. Bogor terletak di Komplek Perumahan Cempaka Citra Indah. Gedungnya sudah berdiri dan sudah digunakan untuk ibadah. Akan tetapi, belum ada Surat Rekomendasi Kementerian Agama Kabupaten Bogor, FKUB Kabupaten Bogor, dan apalagi IMB-nya belum diurus. Kini bangunan tersebut sudah diurus dan sudah diverifikasi oleh Tim yang dibentuk oleh Kemenag dan Kecamatan Jonggol. Sejumlah persyaratan sudah dipenuhi, dengan telah terbitnya Rekomendasi Kemenag, kini tinggal menunggu Rekomendasi FKUB berdasarkan hasil validasi data dari FKUB. ${ }^{12}$

\section{Penutup}

Berdasarkan uraian diatas, dapatlah ditarik beberapa kesimpulan:

1. Peran Pemerintah Daerah (Bupati/ Walikota) dalam mengaplikasikan PBM No. 8 Tahun 2006 dan Nomor 9 Tahun 2006 serta Mekanisme yang ditempuh untuk mengantisipasi terjadinya konflik internal dan eksternal pra dan pasca pendirian rumah ibadah di Indonesia mempunyai peran yang sangat strategis untuk mengantisipasi dan mengatasi serta meminimalisir potensi konflik pra dan pasca pendirian rumah ibadah.

2. PBM ini menyadarkan semua pihak dan para pihak pemeluk agama yang akan membangun rumah ibadah atau mengadakan kegiatan ibadah di tempat sementara, semua tahapan kegiatan itu mesti mengacu kepada hukum positif yang berlaku sebagai pijakan dan pedoman yaitu Peraturan Bersama (PBM) Menteri Agama dan Menteri Dalam Negeri Nomor 9 Tahun 2006 dan No. 8 Tahun 2006.

3. Peran maksimal dari Pimpinan Daerah Bupati/Walikota termasuk struktur yang ada di bawahnya mulai dari RT, RW, Kalur/Kades dan Camat, dan peran maksimal dari Kantor Urusan Agama (KUA) dan Kementerian

${ }^{11}$ Data-Data diambil dari FKUB Kab. Bogor, dan MUI Kab. Bogor.

${ }^{12}$ Data-Data diambil dari FKUB Kab. Bogor, dan MUI Kab. Bogor. 
Agama, serta Forum Kerukunan Beragama (FKUB) mempunyai peranan strategis untuk memberikan kesadaran hukum kepada setiap warga masyarakat pemeluk agama yang berdomisili di wilayahnya, serta selalu mengawal untuk mengklarifikasi, memverifikasi, dan memvalidasi data secara obyektif serta terbuka, dengan terus menghindari jebakan pemberian sesuatu yang mengakibatkan adanya sikap subyektif untuk melakukan manipulasi data.

4. Beberapa kasus yang sangat krusial baik dalam bentuk pra pendirian rumah ibadah atau pasca pendirian rumah ibadah muncul disebabkan adanya permainan yang terselubung di dalam perangkat struktur kepemimpinan RT dan RW, Kelurahan/Desa, Pimpinan Kecamatan, Bupati/Walikota serta jajaran Pemda dan Muspida, sebagai yang terjadi pada kasus GKI Yasmin di Kota Bogor, Gereja Paroki Tulang Kuning, dan Gereja Katholik Hati Kudus di Citra Indah.

5. Jika mekanisme dan prosedur pengajuan pendirian rumah ibadah dilakukan secara obyektif dan terbuka sesuai dengan PBM dan kawalan serta adanya ketegasan dari perangkat pemerintah daerah maka konflik antara pihak tidak terjadi, dan akan tercipta saling asah, asih, asuh menuju Indonesia kuat dan bersatu.

\section{Pustaka Acuan}

Kahmad, Dadang Sosiologi Agama, Bandung: Rosda.

Rabi', Abu, "Christian-Muslim Relations in Indonesia: The Challenges of The Twenty-First Century" Jurnal Studia Islamika (Jakarta: IAIN Syarif Hidayatullah, 1998).

Sudarta, Konflik Islam-Kristen, Menguak Akar Masalah Hubungan Antar umat Beragama di Indonesia, (Semarang: Pustaka Rizki Putra, 1999).

Sumarthana, "Menuju Dialog Antar Iman", Pengantar dalam Dialog : Kritik dan Identitas Agama, (Yogyakarta: Dian/ Interfedei, Seri Dian I/Tahun I, 1993), x-xi.

Sambutan Menteri Agama RI, Muhammad Maftuh Basyuni, pada Acara Sosialisasi PBM di Depdagri, 7 April 2006. 